
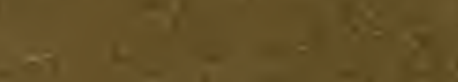

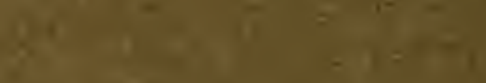

$$
\begin{aligned}
& x^{2}=\mathrm{x}^{2} .
\end{aligned}
$$





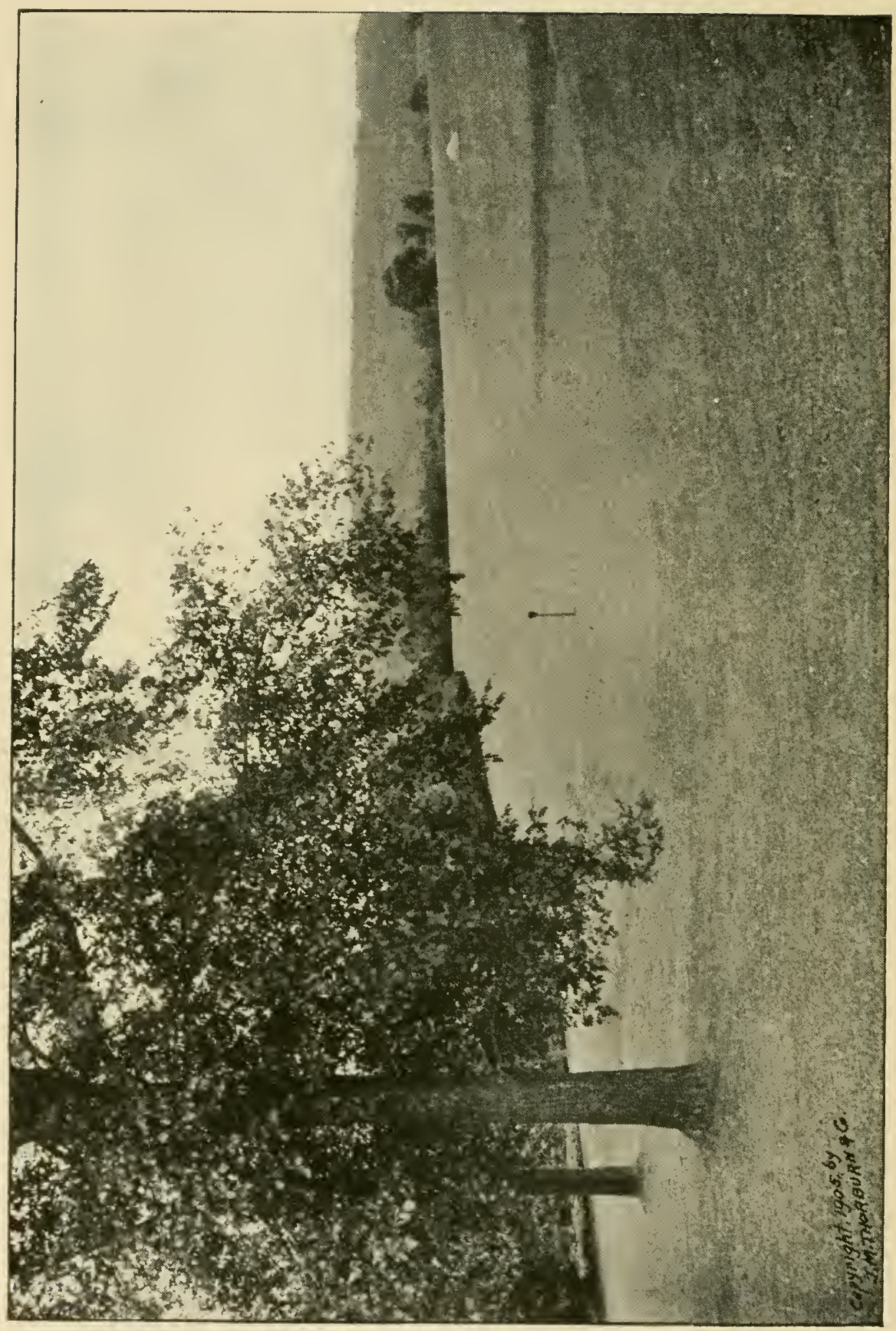




\section{THE SEEDING AND}

PRESERVATION

OF GOLF LINKS

$\mathrm{BY}$

J. M. THORBURN \& CO.

$$
\text { " }
$$

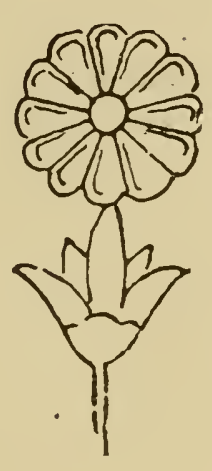

NEW YORK

J. M. THORBURN \& CO.

33 Barclay Street 

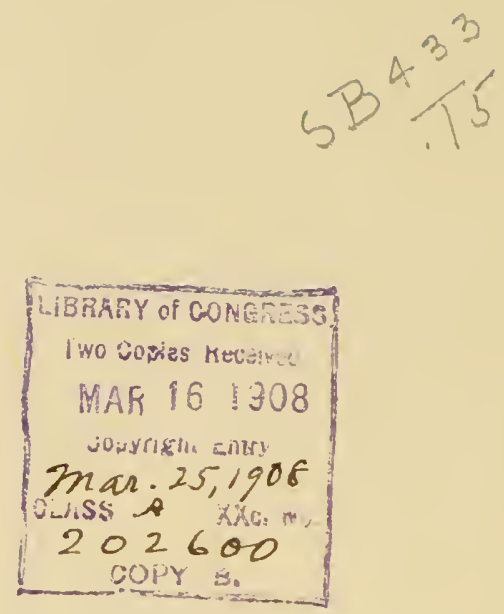

COPYRIGHT, 1908

BY J. M. THORBURN \& CO.

$\because \vdots \vdots$ 


\section{Introduction}

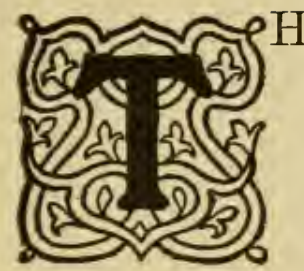

HE preparation of the following pages was suggested by the frequent applications received from golf clubs for information as to the seeding of their grounds. Their aim is to answer the questions that present themselves to greens committees in connection with the formation of new courses, and the maintenance of established ones. These questions are assuming greater importance every year, the constantly improving condition of the older and more favorably situated links raising the standard of what a course ought to be, and the practice of intervisiting keeping that standard constantly in view. Every club is anxious to have for visiting players, especially during the open tournaments, as fine a course as they are accustomed to, and every chairman of greens committee feels the spur of criticisms made by members of his own club on their return from visiting a better course, so that the ideal links will always be, for most clubs, only an aspiration; and it is easier to point out the inevitableness of this state of things than to provide a cure for it. The only approach to a remedy, indeed, in our varied and trying 
climate, is constant care and attention, intelligently directed.

These incentives to the improvement of the grounds have assured the future of golf in America, and those gentlemen who have assumed the burdens of the work have done more for the cause of the game than they are generally credited with. For to the majority of its votaries the charm of golf will always include the freshness of the country air, and the exhilaration of walking on a green elastic turf, untiring to the foot and pleasing to the eye.

\section{Important!}

Too much stress cannot be laid on the importance of securing the best seed.

It must be remembered that there are many grades of the various sorts offered for sale. The best is none too good.

We have for many years made a specialty of grass seed, and we import and deal in the highest grades only, so that those who entrust their orders to us can have the assurance that they will receive the very best the market affords. 


\section{Turf-forming Grasses}

THE first condition of success in securing a 1 good golf course is a due recognition of the relation between soil, situation and climate on the one hand, and the different varieties of grasses on the other. As every grass has its own peculiar habit and habitat, the whole inquiry resolves itself into two questions: First, what varieties are suitable for golf links; and, second, which of these are, at the same time, adapted to the peculiar soil and situation under consideration?

The first question is easily disposed of, as it is obvious that all turf-forming varieties are suitable, without regard to their particular shade of color or fineness of texture. These niceties will be considered separately in connection with the putting-greens. "Bunch grasses," that is, grasses that grow, like Orchard Grass, in tussocks or detached bunches, are excluded, and only those of a prostrate habit of growth, or with creeping, interlacing roots, are admissible. The following list includes all the distinctive and longest lasting of these, and the answer to the second question is supplied by our account of the conditions under which they thrive. 
AGROSTIS CANINA (Rhode Island Bent Grass). Resembles Red Top (A. rulguris, described below), but is of dwarfer habit, with shorter and narrower leaves. It makes a beautiful, close, fine turf, and is one of the very best grasses for lawns. It adapts itself to almost any soil, rich and moist, or dry, sandy and sterile. It is a native of Europe, but has been cultivated in our Eastern States for many years, being valuable for permanent pastures. The meadows, however, from which it has been saved here have of late run largely into the freer seeding Red Top, so that we now import it from Europe, where it has been more carefully cultivated. Fifty to 60 pounds of seed to the acre is recommended for lawns.

AGROSTIS STOLONIFERA (Creeping Bent, or Fiorin). The distinctive feature of this species is, as the name implies, its compact, creeping, rooting stems. It prefers low bottom lands, especially if they are somewhat sandy. It is of rapid growth and spreading habit, and the stoloniferous roots form a strong, enduring turf, that is positively improved by constant trampling. Being of fine texture, it is one of the most valuable of our lawn grasses. If sown alone, 50 pounds to the acre should be used.

Agrostis VULGaris (Red Top; Herd's Grass). A very hardy native perennial grass, succeeding best on moist land. It accommodates itself to a variety of soils, however, even to quite dry situations, and stands our hot climate admirably. It is, perhaps, the most permanent grass we have, and it enters largely into the composition of our best natural pastures. It remains green for the greater part of the year, and its long, trailing stems form a very close, matting turf, that is not affected by trampling. It grows well as far south as Tennessee. Of the absolutely clean or "fancy" seed, 30 pounds to the acre is sufficient.

ALOPECUPUS PRATENSIS (Meadow Foxtail). One of the best permanent pasture-grasses for rich, moist lands. Its chief characteristics for our purpose are its extreme 
earliness and its faculty of standing high summer heats without burning. Although it prefers moist, low grounds, it accepts drier situations, and makes an earlier spring verdure than any other variety. It should be sown only in connection with other grasses, 4 or 5 pounds to the acre.

CYNODON DACTYLON (Bermuda Grass). Decidedly the most valuable grass for southern golf links. It is of dwarf habit, with long creeping stems, rooting at the joints and covering the ground with a matting of fine turf, which no amount of trampling will impair. As it cannot endure frost, it is of no value north of Virginia. It thrives in the poorest and sandiest soil, and resists extreme drought and the most intense tropical heat. It should be sown at the rate of 20 pounds to the acre.

CYNOSURUS CRISTATUS (Crested Dog's tail). A stoloniferous perennial forming a smooth, compact and lasting turf. It thrives best on rich, moist land, but it can accommodate itself to almost any soil. Its roots penetrate deeply into the ground, which enables it to stand severe droughts. It is, on this account, valuable for hilly situations. The texture of its turf is well adapted for putting-greens. If sown alone, 40 pounds to the acre is none too much, but it is recommended only in mixture with other sorts.

FESTUCA DURIUSCULA (Hard Fescue). This is really a "bunch grass" and not a creeping-rooted species, but it may be recommended in mixture for high, dry, sandy soils, where most other grasses would not grow. It thrives in such soils, and can endure long periods of drought and extreme summer heat. Forty pounds to the acre.

FESTUCA RUBRA (Red Fescue). A creeping-rooted species, forming a close and lasting turf, and specially adapted for dry, sandy soils. It resists extreme drought, and thrives on very inferior soils, gravelly banks and exposed hillsides. It is also valuable for binding shifting sands on the sea-shore. As a lawn grass, its chief merit is 
for positions too shaded for better sorts. Thirty pounds to the acre.

FESTUCA TENUIFOLIA (Slender Fescue). This is really a variety of Festuea orina, and not a turf-forming species. It will grow on very dry and inferior soil, however, and its dwarf habit of growth and fineness of leaf render it not unsuitable for such situations in fair-greens. It is one of the finest leaved grasses we have. Forty pounds to the acre.

LOLIUM PERENNE (Perennial Rye Grass). Although called a perennial, it seldom lasts more than three or four years. It is the most valuable grass of Great Britain, both for pastures and for meadows, occupying there the same relative position of importance that Timothy holds here. The cool, moist climate of England seems to suit it best, yet it succeeds very well in our Middle and Eastern States, and adapts itself to a great diversity of soils. The seed is large and heavy, and produces a strong, verdant growth in four or five weeks after sowing. There are several varieties of the Perennial Rye Grass. That known as "Pacey's" is of very vigorous growth, and of a more bushy and leafy habit than the type. It is excellent in mixtures for strengthening and enlivening the turf of fair-greens. Sixty pounds to the acre.

LOLIUM ITALICUM (Italian Rye Grass). Though lasting two or three years under very favorable circumstances, it is practically an annual. Like the Perennial Rye Grass, it is a remarkably rapid grower, and has, in addition, the advantage of standing extremes of temperature, remaining green throughout the winter, and retaining its freshness in the hottest summer months and during prolonged droughts. When sown very thickly, or in mixture with other sorts, it makes a good, dense turf, and it has been used with much satisfaction on lawns as far south as Jacksonville. On rich, moist soils it is exceedingly productive, and it also does 
fairly well in less favored situations. Fifty pounds to the acre.

POA COMPRESSA (Canada Blue Grass). A very hardy perennial grass, with creeping root-stocks, forming a close and durable turf of fine texture. It grows on the poorest and driest soils, sandy, gravelly or clayey, standing extremes of wetness or drought, and keeping green till the severe frosts of winter. It is distinguished from the Kentucky Blue Grass by its flattened, wiry stems and by its decidedly bluer color. Sixty to 70 pounds to the acre.

POA NEMORALIS (Wood Meadow Grass). The chief characteristic of this grass is its special fitness for shaded positions in lawns and woodland parks, where other grasses will not grow. It is very permanent and hardy, resisting extremes of heat and cold, and is one of the first grasses to show a rich green growth in the spring. The creeping roots are formed underground, and make a good turf. Thirty pounds to the acre.

POA PRATENSIS (Kentucky Blue Grass; June Grass). One of our most widely distributed and valuable native grasses. It combines more points of excellence than any other sort. It is a true perennial, lasting indefinitely and improving every year. Its densely creeping root-stocks, spreading habit, and smooth, even growth, fine texture and rich green color render it one of the very best grasses for golf links. It forms a close turf, starts very early in the spring, and lasts till frost. It succeeds in almost any soil, dry, rocky, sandy or gravelly, and stands long-continued dry weather and hot suns. It takes, however, two or three years to become well established and should, therefore, be sown only in connection with other grasses. If the soil is specially suitable it will eventually crowd these out, and make the finest possible sward. Forty-five pounds to the acre. 
POA TRIVIALIS (Rough-stalked Meadow Grass). A spreading, thickly matting, stoloniferous-rooted species, forming a fine turf, and well adapted for the more shaded portions of lawns. It thrives on rich, moist soil, and in sheltered situations, but does not do well on dry land. Twenty pounds to the acre.

WHITE CLOVER (Trifolium repens). Some White Clover is usually included in lawn grass mixtures. It is of dwarf habit, the stems creeping and rooting at the joints. It spreads rapidly, and is very hardy, resisting extremes of heat and cold, dryness and humidity, and accommodating itself to all kinds of soils. The seed should be sown in the spring - not more than two pounds to the acre.

\section{The Theory of Grass Seed Mixtures}

The above list comprises all grasses suitable for golf courses. Their different characteristics at once suggest the propriety of selecting particular sorts to meet particular conditions of soil, situation and climate. It does not follow, however, that the best results are always obtained by sowing any one variety, for it is a well-ascertained fact, fully recognized by all successful agriculturists, that a thicker and more prolonged growth is produced by a mixture of several sorts than by only one or two, and that a combination of grasses may thrive on a piece of ground on 
which any one of them would succeed indifferently. Our present concern is not with the explanation of this fact, but with its significance. It is obvious that a mixture of various sorts simplifies the task of selecting the grass to sow, and minimizes the risk of failure. For out of many varieties there will always be some to succeed, even if others should fail. This is a very important consideration in a climate like ours, where, on certain soils, prolonged droughts and hot weather might completely burn up a turf composed of one species. In a mixed turf the several sorts are mutually helpful in such a case, the very decay of some of them serving as a mulch and protection to the others. But apart from these contingencies, mixtures have a peculiar fitness for golf grounds, in that they insure an abundance of verdure for the greater part of the year, some being at their best very early in the spring and others not till late in the fall.

It is true that there are individual species, like Kentucky Blue Grass, that start very early in the spring and maintain a vigorous growth till winter sets in. They do this, however, only after they have become well established in soils that are eminently suited to them; and when the conditions are specially suited to a particular speciest all others will be crowded out in a few years, anyway. Here, as elsewhere, the struggle for existence results in the survival of the fittest.

For practical purposes, then, it is sufficient to consider the general character of the ground to 
be seeded, whether high and dry, low and wet, or a good soil between the two. A mixture of five or six of the above-described grasses, preferring corresponding conditions, is sure to give satisfactory results. 


\section{Formation of Putting-greens}

$7 H E$ preceding chapter is intended to apply to the seeding of the fair-greens or grounds in general, where the grasses must, from the nature of the case, be chosen to suit the ground. But for the putting-greens the ground may be made to suit the grasses. Their limited area makes this possible, and the fact that only a few grasses will give the required quality of sod and fineness of texture makes it necessary. Eighteen greens, each 100 feet square, cover only four acres of ground,-a space which can easily be given sufficient care and attention to produce a perfect and permanent turf. The unsatisfactory condition of many of our puttinggreens is due neither to the climate nor to neglect, but to the initial mistake of sowing unsuitable grasses on imperfectly prepared soil. In their eagerness to begin play, new clubs often plan their putting-greens on the best parts of the existing turf. It may safely be asserted that no amount of care or patching will ever convert these spaces into good greens. Another common method is sodding with transplanted turf. This may be done with success, when good turf of pure Kentucky Blue Grass or of the bent grasses can 
be obtained. Turf of this description is not uncommon in the old pastures of our middle and eastern states. We say old, because the grasses mentioned are those that would naturally be in possession after a number of years, all others being crowded out by them. Where the matter of expense is unimportant and such turf available, some time may be saved and fairly good results secured by sodding. Those who adopt this plan must observe carefully the following necessary conditions of success: The soil must be deeply dug and a liberal supply of barnyard manure or other fertilizer worked into it. The surface should be soft and finely pulverized, and the sod pressed down as firmly as possible upon it. The heaviest roller will not press it too firmly. A covering of half an inch of fine soil, through which the grass will quickly grow, will prevent the turf from drying out.

As a rule, putting-greens formed either by patching the existing turf or by sodding with transplanted turf, are only make-shifts, although under the conditions above mentioned the latter plan has been known to give good satisfaction. The simplest and surest plan is to make the greens by seeding with grasses peculiarly adapted for the purpose.

The first and most important step is to prepare the ground thoroughly. Trenching to the depth of two feet will insure proper drainage, and enable the grasses to penetrate deeply into the soil. The deeper and freer the root-growth 
the more able will they be to withstand summer droughts and severe winters. If the work can be begun in the fall, so much the better. In trenching, the soil should be thoroughly pulverized, and an abundant quantity of well-rotted stable manure worked into it. The following spring a dressing of ground-bone and chemical fertilizer should be applied, the soil again turned over, the surface finely pulverized by raking and rolling, and levelled to a perfect grade.

Referring now to the list of turf-forming grasses given in a former chapter, we observe that the first two species of Agrostis; viz., Rhode Island Bent Grass and Creeping Bent Grass, and Cynosrus cristatus, are suitable for forming the quality of turf required on a putting-green. Their low, creeping, densely matting habit, fine, yet not too fine, foliage, their great permanence, and their peculiar quality of improving the more they are tramped upon, all suggest special fitness for this purpose. A mixture of these sorts should be sown, the greater proportion being Creeping Bent on low, moist soils, and Rhode Island Bent on high, dry land. (In the states south of Virginia Bermuda Grass should be used.) In this section these grasses, sown during the latter part of March, on soil so prepared, will produce a turf fit for play by September, and one which will keep on improving indefinitely. If the seed is sown on the newly raked surface, it need not be covered. The ground must be rolled, however, to press the seed into the earth and to give the final smoothing to 
the surface. In sowing, care must be taken to distribute the seed evenly, and not in patches. A very liberal quantity is recommended of the bent grasses, - - say 25 pounds of clean seed to each green of 100 feet square. 


\section{Time of Sowing}

THE proper time to sow grass seed depends, of course, upon the latitude. In the central and eastern states from the middle of March to the middle of May (and frequently to middle June, according to season) is the best time. If sown later, the grasses may not be strong enough to stand the hot, dry summer months. Seed may also be sown in the fall, provided it is done early enough to secure a good, strong growth before winter sets it. If the young plants are not wellrooted, they are liable to be killed by frost or thrown out of the ground by the action of alternate freezing and thawing. That is the objection to late fall sowing. The advantage of it is that, if the grass comes safely through the winter, it has a good start in the spring. The sowing should be done when the ground is moist, or before an expected rain, and a subsequent rolling is always advisable, in order to press the seed into the soil. Seed for the putting-greens should be kept always on hand, and before every rain in summer it should be sown on any thin or burnt-out spots that may appear. 


\section{Weeds}

DAN HERBERT said that "plants do not grow where they like best, but where other plants will let them." The remark is peculiarly applicable to weeds - of all kinds. They are most in evidence the first season, before the grass has become well established, occupying every thin or bare spot. But once a close turf has been formed, they will cause little trouble. The only way to get rid of them is to sow enough grass seed to crowd them out and prevent the introduction of others. With a few exceptions they are all annuals, dying at the approach of winter. Let the spots occupied by them be scarified in the spring with a steel rake, or harrowed, if the area is large; then apply some chemical fertilizer and sow grass seed. The weeds will not appear in these spots again. The perennials, however, such as dandelions, docks and plantains, are not so easily disposed of. These must be pulled out by the root and grass seed sown in their places. Most weeds are easily kept down by the lawn-mower, and, except by their unsightliness, cause little trouble to golfers. One important exception deserves particular notice. Its scientific name is Panicum sanguinale, but it is best known and least esteemed 
as "crab grass", and "summer grass." It lies low before the mower and springs up elastic behind it,-refusing to be cut. It is a most aggressive expansionist, seizing upon any spot that offers it standing room, and crowding out everything that cannot resist it. It is most conspicuous and unsightly in the early fall, when it turns brown. By the end of autumn it is dead. It leaves, however, much seed of very great vitality which will come up again the following year and crowd out the finer grasses. If in the fall it is found that this grass exists it is important that the plants of it be at once cut out, so that they may not seed. If fertilizer is then applied and grass seed thickly sown, the space may be saved from next year's invasion of this pest. There is no other remedy. Crab grass grows wherever other grasses will let it, and nowhere else. 


\section{Earthworms}

THE genius of Charles Darwin was devoted to

a long and exhaustive study of the action of earthworms, and his experiments proved conclusively that their borings and castings have a very beneficial influence on grass lands. $\mathrm{He}$ estimated that over ten tons of dry earth per acre are passed through their bodies annually, undergoing, in the process, a grinding that greatly improves its quality as soil. While we recognize the annoyance caused by worm-casts on puttinggreens, we hesitate to suggest any means of destroying these useful creatures. It is, of course, impracticable to do so over a large area, but on grounds where they are particularly troublesome the selection of fertilizers might be made with a view to keeping them under. The alkaline effect of wood-ashes is very irritating to them, and they cannot stand quick-lime. On putting-greens earthworms might be destroyed by saturating the ground with a kerosene wash, or ground charcoal might be spread over the greens in the spring; but, even there, it is probably as well to put up with their operations and to minimize the trouble they cause by brushing their castings off, or over, the greens lightly with a broom. A distinguished golfer recommends the following formula: Take $1 / 8$ oz. corrosive sublimate and mix with two quarts of water; then add 40 or 50 gallons of water and sprinkle the ground, using an ordinary wateringpot. 


\section{Fertilizers}

$7 \mathrm{HE}$ essential elements of fertilizer for grass 1 lands are nitrogen, phosphoric acid and potash, because these are the chemical elements which the grasses in growing appropriate in largest quantity, and which are present in the soil in smallest proportion. All the common manures and commercial fertilizers contain these elements in greater or smaller quantity, and are valuable proportionately, so that it really does not matter what kind of fertilizer is used, provided these necessary elements are rendered available as food for the plants. The matter of availability is very important, for it is obvious that the fertilizing constituents are useless unless they are in a form in which they can be assimilated by the plants. This fact suggests the propriety of using particular forms of manure or fertilizer, according to the conditions of the soil and the manner of application.

STABLE MANURE. This is decidedly the best and most economical form of fertilizer to use in the initial preparation of the ground for permanent grass lands. A too liberal quantity can hardly be applied. A very heavy dressing, plowed in in the fall, and another dressing cross-plowed in the following spring are recommended. This manure con- 
tains all the "essential manurial elements," but in a form more or less insoluble. They become available slowly and continuously, as the manure decays. Besides being one of the best direct fertilizers, this form of manure has a most valuable mechanical effect in improving the condition of the soil-the vegetable matter in it making stiff, clayey lands more porous and a too light soil more compact. But, although there is nothing better for plowing under, it is by no means as economical when used as a top-dressing. For when so applied the mechanical effect above mentioned is only slightly exercised, and much of the fertilizing properties is lost by the long exposure to the atmosphere. These considerations, and the extra labor involved in spreading in the fall and removing the coarse vegetable parts remaining in the spring, make the natural manure less desirable for surface application than some of the other forms of fertilizer. Its liability to contain weed seeds is still another objection to stable manure for top-dressing.

GROUND BONE. As a fertilizer for grass lands, ground bone comes next in importance to barnyard manure. In the preparation of the ground, a liberal quantity of the coarser grade should be well worked into the soil, where it decomposes slowly, furnishing a continuous supply of nitrogen and phosphoric acid. For top-dressing, the finer grade, known as "bone meal" or "bone flour," should be used. There is nothing better than an early spring dressing of this at the rate of half a ton to the acre. On puttinggreens it might be supplemented by nitrate of soda, at the rate of 300 pounds to the acre, because the nitrogen in the bone is somewhat slow to become available.

CHEMICAL FERTILIZER. A high-grade complete chemical fertilizer is probably the surest and most effective spring top-dressing for grass. It contains all the essential elements in a highly concentrated and quickly available form. Half a ton to the acre is sufficient on an ordinary soil. To ensure even distribution, it should be mixed with equal bulk of dry earth. Such a fertilizer is also excellent 
for working into the soil when making putting-greens. Chemical fertilizer should be bought guaranteed or subject to analysis.

SHEEP MANURE. In the pulverized form in which it is usually sold, this manure makes an excellent top-dressing. It may be applied either in the fall or early spring, at the rate of three or four tons to the acre. It contains nearly twice as much solid matter as horse manure, and is very rich in phosphoric acid, nitrogen and potash. It also adds humus to the soil, which chemical fertilizers do not. Mixed with water-1 pound to 5 gallons-and a little muriate of potash added, it makes a most effective liquid fertilizer for putting-greens.

WOOD ASHES. The fertilizing value of unleached wood ashes is due to the potash which they contain. To make a complete fertilizer it would be necessary to add some phosphoric acid and nitrogen. For this purpose 1,000 pounds bone meal and 300 pounds nitrate of soda to the acre would answer. Any quantity of the ashes may be used,-3 to 5 tons to the acre. They have an important mechanical effect in lightening the soil. Leached wood ashes contain only 1 per cent. potash and have practically no fertilizing value. In purchasing, care should be taken to get pure and unleached ashes.

NITRATE OF SODA.- In stimulating the growth of grass, nitrate of soda is the most quickly effective top-dressing, the nitrogen in this form being immediately available. It is extremely soluble, and penetrates deep into the soil, thus promoting a stronger and deeper root-growth. It is very valuable to promote a quick growth on new grasslands and should be applied preferably when the young grass is 2 or 3 inches tall. Two or three slight dressings at intervals throughout the season are recommended in preference to one heavy application. An equal quantity of bone meal mixed with it would supply the requisite phosphoric acid. For a putting-green 100 feet square, 40 pounds of this mixture would be sufficient at a time. 


\section{Rolling and Mowing}

PLLING.-As soon as the frost is out of the ground in the spring, the land should be gone over with a heavy roller. Winter frosts loosen the soil, and rolling is necessary to compress it again. If grass seed is to be sown, this should be done first and the rolling immediately afterwards. Frequent rollings are recommended.

Mowing.-All turf-forming grasses are improved, both in vigor of root-growth and in fineness of texture, by frequent mowings. It is impossible to say just how often the grass should be mown, as that depends upon the rate at which it grows. In the spring and early summer, when the growth is most vigorous, three cuttings a week are recommended for putting-greens. Too close cutting should be guarded against, however, especially during the hot summer months, when the roots require some top-growth to protect them from the burning sun. For the same reason it is as well not to rake off the cut grass, as it quickly settles about the roots and forms a valuable protective mulch. A good top-growth is also necessary to protect the roots from severe winter frosts. Mowing should therefore be discontinued in time to let the grass grow pretty long before winter sets in. 


\section{J. M. THORBURN \& CO.}

\section{Seedsmen}

\section{BARCLAY STREET, NEW YORK (LATE OF 36 CORTLANDT STREET)}

\section{Established 1802}

$\mathrm{F}^{\mathrm{on}}$

R over a hundred years our house has made a specialty of grasses. We were probably the first to introduce to this country, for commercial distribution, the many valuable natural and cultivated foreign species that now take such an important part in our agricultural economy. The formation of permanent pastures and meadows has for many years been a subject of careful study with us, and our celebrated formulæ for seeding grasslands have received universal recognition.

We have given similar attention to lawngrasses, and our thorough knowledge of the subject enables us to prescribe the most suitable kind for all soils, situations and climatic conditions. Most of the very finest lawns from Florida to Canada were produced by seed prescribed and 
furnished by us. We could justify this statement by thousands of testimonials if space would permit.

What we have done for lawns and pastures we can do for golf links also. Our knowledge of grasses and their requirements is the outcome of close observation and long experience. Besides being able to give sound advice, our position as large wholesale dealers in grass seeds enables us to supply the required varieties, of the highest grade and at the lowest prices. We invite Greens Committees to consult us, either personally or by letter.

Our general seed Catalogue contains a full descriptive list of all valuable natural and cultivated grasses and clovers, both foreign and domestic. We shall be glad to mail it on application. Where large quantities are required we shall quote special prices, at same time submitting samples if desired. Grass seeds can only be bought intelligently by sample, as their value depends so much upon weight and purity.

The following celebrated courses were obtained from the use of grasses and fertilizers prescribed and furnished mainly by us:

St. Andrews Golf Club
Wee Burn Golf Club
Apawamis Golf Club
Nassau Country Club
Hackensack Golf Club
Nashville Golf Country Club.
Essex County Country Club
Chicago Golf Club
Philadelphia Country Club
Baltusrol Golf Club
Upper Montclair Country Club
Calumet Country Club

Rockland County Country Club

GEO. W. Vanderbilt's Biltmore Estate

Allegheny Country Club

Shinnecock Hills Golf Club

Montclair Golf Club

Englewood Golf Club

Oakmont Country Club

Buffalo Country Club

Woodlawn Cemetery.

Morris County Country Club 


\section{FERTILIZERS FOR LAWNS AND GOLF LINKS}

\section{Thorburn's Grass Fertilizer}

Guaranteed to contain ammonia, 6 to 7 per cent; phosphoric acid, all soluble, 8 to 10 per cent; actual potash, 5 to 6 per cent; lime, sulphate of magnesia, soda, sulphuric acid, etc. Specially prepared for top-dressing lawns and golf links, imparting to grass a rich green color and vigorous growth. Being very powerful, half a ton is sufficient for an acre on soil not impoverished.

PRICE-In 167-lb. bags, per ton, \$50; single bags of 167 lbs., \$4.50.

\section{Pulverized Sheep Manure PRICE-Per 100 lbs., \$2; per ton, \$28. \\ Unleached Hardwood Ashes PRICE-\$22 per ton.}

\section{Bone Fertilizers}

Pure Ground Bone Meal. This finely pulverized ground bone is excellent for top-dressing. It decomposes very rapidly, and is more quickly effective than the coarser grade. 100 lbs., \$2; per ton, \$30.

Ground Bone No. 2. This is coarser than the above, and is suitable for working into the soil. It decomposes slowly, furnishing a continuous supply of nitrogen and phosphoric acid. Per 100-1b. bag, \$2.25; per ton, $\$ 36$.

\section{Nitrate of Soda}

Furnished always at market price, which fluctuates considerably.

N. B.-On large quantities of above Fertilizers special prices will be quoted. 


\section{GRASS SEED MIXTURES}

\section{PERENNIAL GRASSES FOR GOLF LINKS.}

For Fair

We prefer to make special mixtures to suit the particular conditions of soil and situation. If correspondents will describe the nature of the land to be seeded, whether dry, moist or medium, and whether clayey, sandy or loamy, we shall recommend a suitable mixture, and quote price at same time.

For Putting-Greens. Our finest possible mixture for puttinggreens. Price per bushel of 24 lbs., $\$ 7$.

\section{FOR IAINNS.}

Thorburn's Lawn Grass Mixture. The finest possible mixture for lawns. It should be sown at the rate of 4 to 5 bushels to the acre. Price per bushel of $15 \mathrm{lbs}$, $\$ 3.50$.

Thorburn's Lawn-Restoring Mixture. A mixture of grasses peculiarly suited to take firm hold and grow quickly on hard, worn-out or burned spots. The bare spots should be well scratched or raked up, and this seed sown liberally. Cover very thinly with earth, and then roll or press down firmly with the back of the spade. Some Lawn-Restoring Grass Seed should be kept always on hand, and before every rain during the summer some of it should be sown on any part that may appear thinner than the rest. Price per quart-box, $30 \mathrm{cts}$; per bushel of $24 \mathrm{lbs}$., $\$ 5$.

\section{FOR MEADOIV AND PASTURE.}

We invite country gentlemen to send for our circular of formulie for permanent meadows and pastures. It gives the names of the grasses used and the proportion of each. They are all made so as to be sowr at the rate of $40 \mathrm{lbs}$. seed to the acre. Our prices, per acre, are as follows:

PERMANENT MEADOWS-

No. 1. For good land, neither too dry nor too wet. $\$ 6.00$ per acre.

No. 2. For high and dry land................ 7.00 "

No. 3. For wet, late land................... 6.00 "

PERMANENT PASTURES-

No. 4. For good land, neither too dry nor too wet. 7.00 “"

No. 5. For high and dry land................. 8.00 "

No. 6 . For wet, late land..................... 7.00 "

Our General Catalogue gives full description and prices of all valuable natural and cultivated grasses and clovers. It is mailed free on application. 


\section{THORBURN'S SPECIAL LAWN GRASS MIXTURE.}

This extra-choice mixture contains a large proportion of the finer and more expensive species, such as Rhode Island Bent, Crested Dog's-Tail, Creeping Bent, in extra-heavy samples, bringing the weight up to 20 pounds par bushel, and producing a turf of the closest and finest texture possible. Price per bus. of $20 \mathrm{lbs}$., $\$ 5$.

\section{THORBURN'S LAWN GRASS FOR THE SOUTH.}

A mixture of grasses that stand extremes of heat and drought well and that are therefore peculiarly adapted for Southern lawns. Bus. of $20 \mathrm{lbs} ., \$ 6$.

\section{THORBURN'S GRASS MIXTURE FOR SHADY SPOTS ON LA IVNS.}

A mixture of grasses that thrive in shaded situations, under trees, or close to walls where there is little sun. Bus. of 24 lbs., $\$ 6$.

\section{THORBURN'S SPECIAL LAIVN GRASS MITURE FOR THE SEASHORE.}

A mixture of fine grasses peculiarly suited to seaside lawns. Bus. of 20 lbs., $\$ 5$.

\section{POLO-GROUNDS MIITURE.}

A mixture of fine-leaved and deep-rooting grasses, forming a strong and lasting turf that will stand hard usage. Per bushel of 20 pounds, $\$ 3.25$.

\section{TENNIS-COURT MXTURE.}

A mixture of extra-fine grasses peculiarly adapted for tenniscourts. This mixture will make a firm, green and lasting turf of finest texture, that will improve with tramping. Bus. of 24 1 bs., $\$ 7$. 


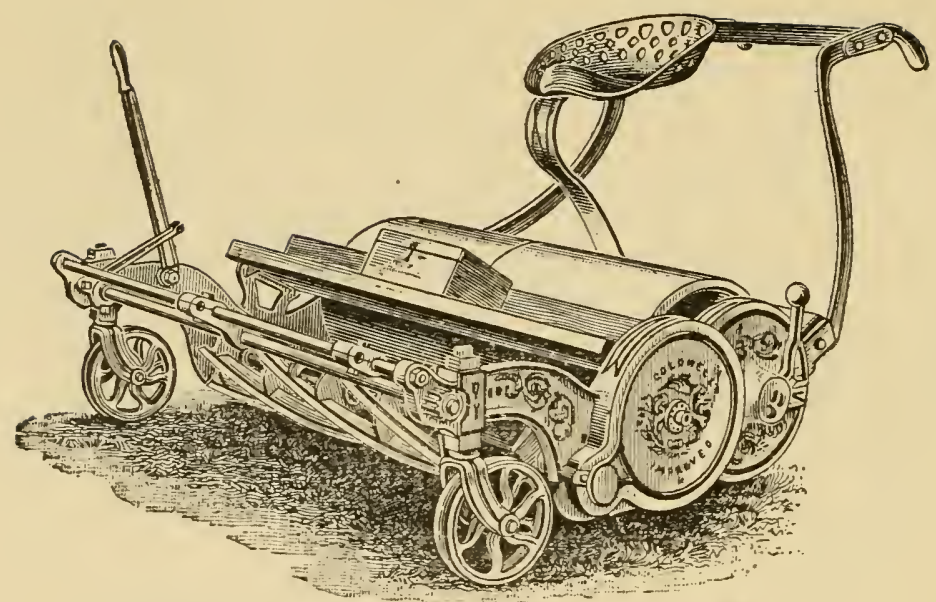

\section{Coldwell Improved Horse Lawn Mower}

This well-known standard Mower has side-draft attachment, to enable the horse to walk on the cut grass only, and caster-rollers, which will not mark the lawn. Evenness of cut is assured by an adjustment which raises or lowers the two sides at the same time by means of a simple lever movement; the same lever serves the purpose of raising the knives from the ground when driving over gravel walks or roads.

NET PRICES free on board New York

25-in. cut, no shafts, \$38. | 35-in. cut, complete, $\$ 78$.

30 -in. cut, complete, \$65. 10 -in. cut, complete, $\$ 95$.

\section{Capitol Lawn Trimmer and Edger}

For trimming close to walls or fences. A useful labor-saviug device. Price, $\$ 6$ each

\section{Cast-Ipon Hand Lawn Roller's}

All Sizes. See Our General Catalogue

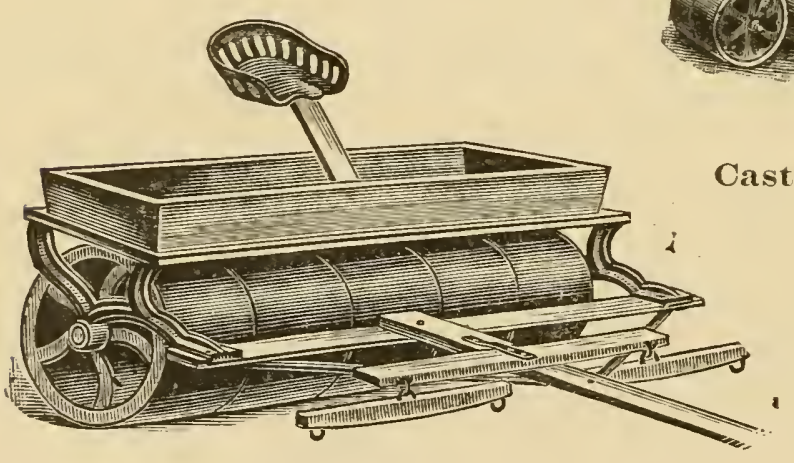

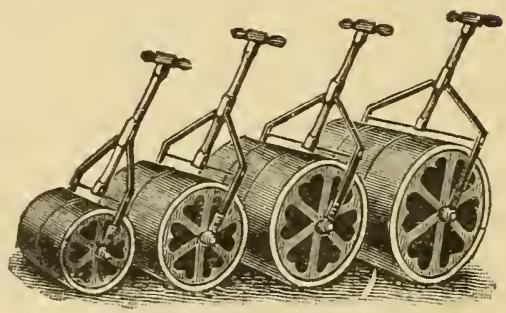

Cast-Iron Horse Land Rollers

With either Pole, for two horses, or Shafts, for one horse. Prices on application. 


\section{The Thorburn Century Ball- Bearing Lawn Mower}

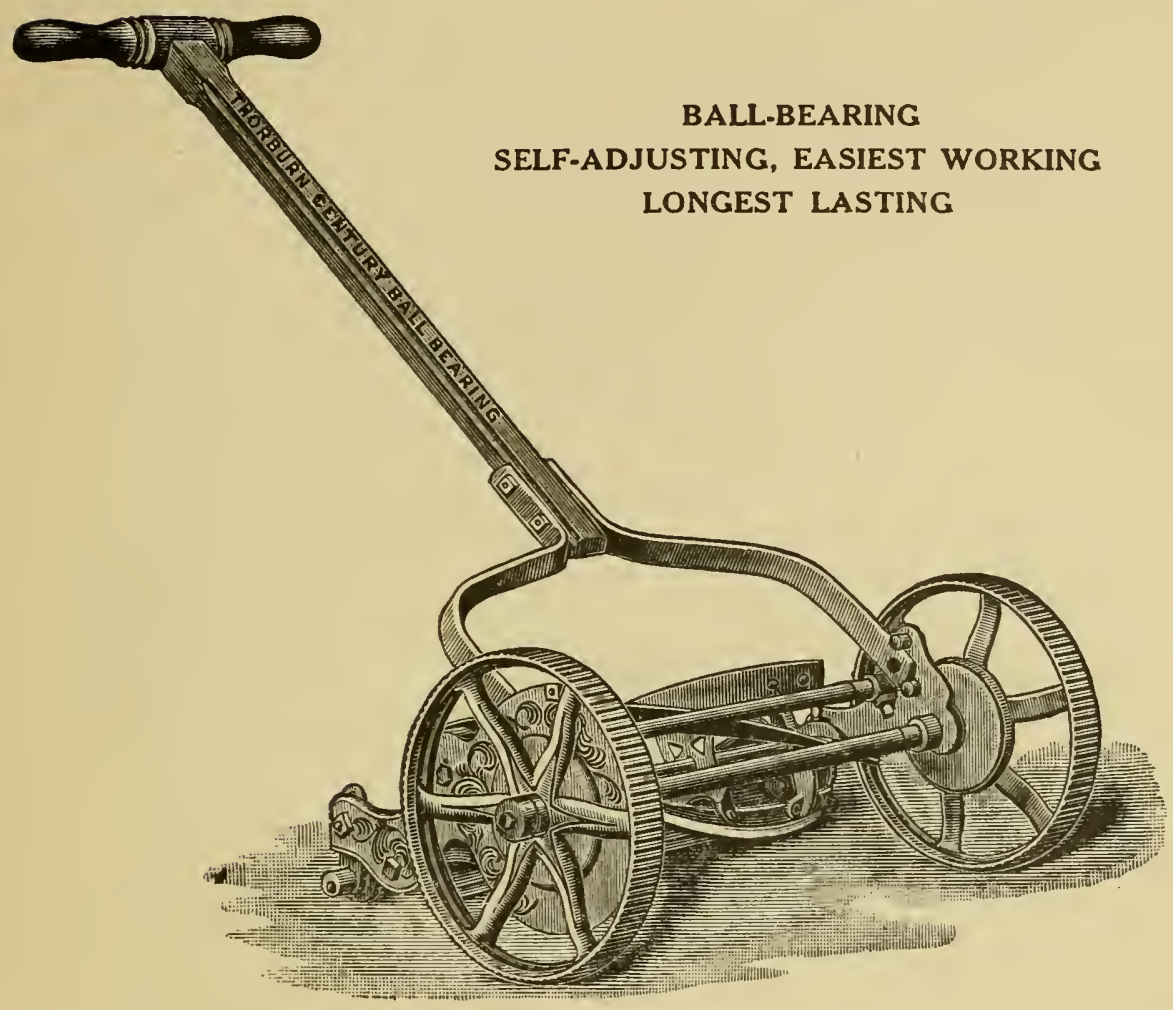

A 20-inch cut machine can be used with greater ease than a I6-inch cut old style mower.

\section{PRICES}

14-inch cut . . . . \$8.50 I8-inch cut . . . \$10.50 16 " " . . . . . 9.5020 " $9 . \quad$. . . 11.50

Special prices to Golf Clubs requiring a number of them 


\section{Chain Roller or Golf Mower}

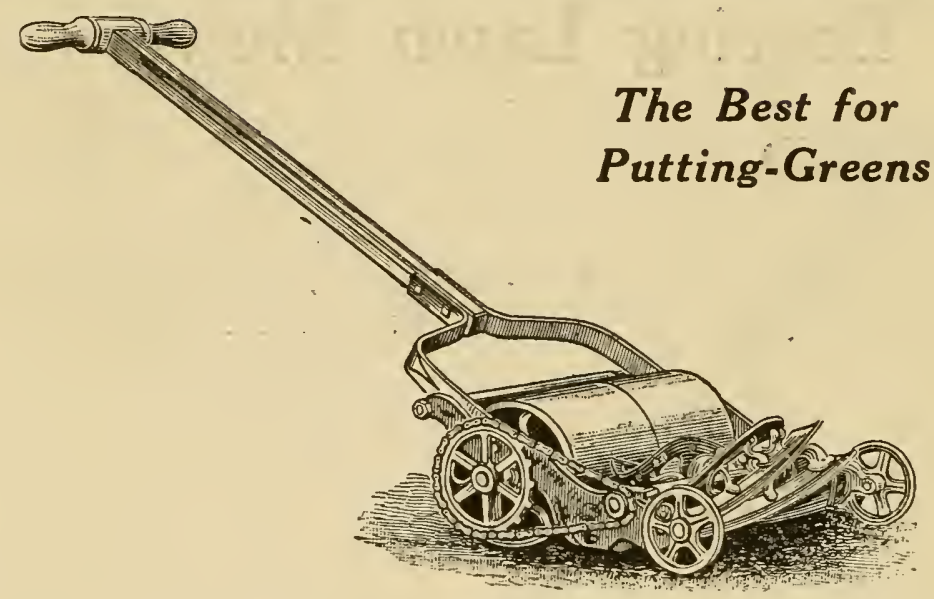

This mower is made to meet the demand for a machine that will more perfeetly cut borders, verges, etc., and yet retain all the other features necessary in a mower for general work. The great advantage of this mower is the substitution of a bicycle chain for the gears generally used in this style of mower. This reduces the friction to a minimum. The machine with six blades is highly recommended by most of the leading golf clubs in America for work on putting-greens.

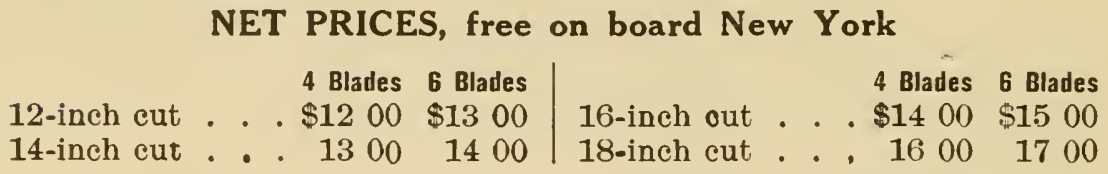

\section{HORSE BOOTS}

Made of very strong, heavy lleather, closely riveted. Price per set of four, $\$ 9$. Reinforcedinside.with steel plate, per set of four, \$11.

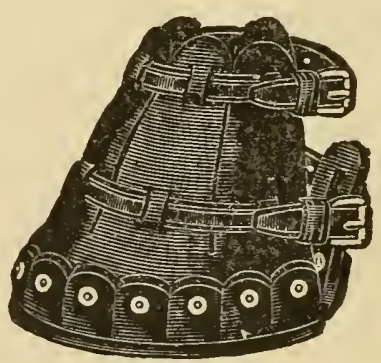




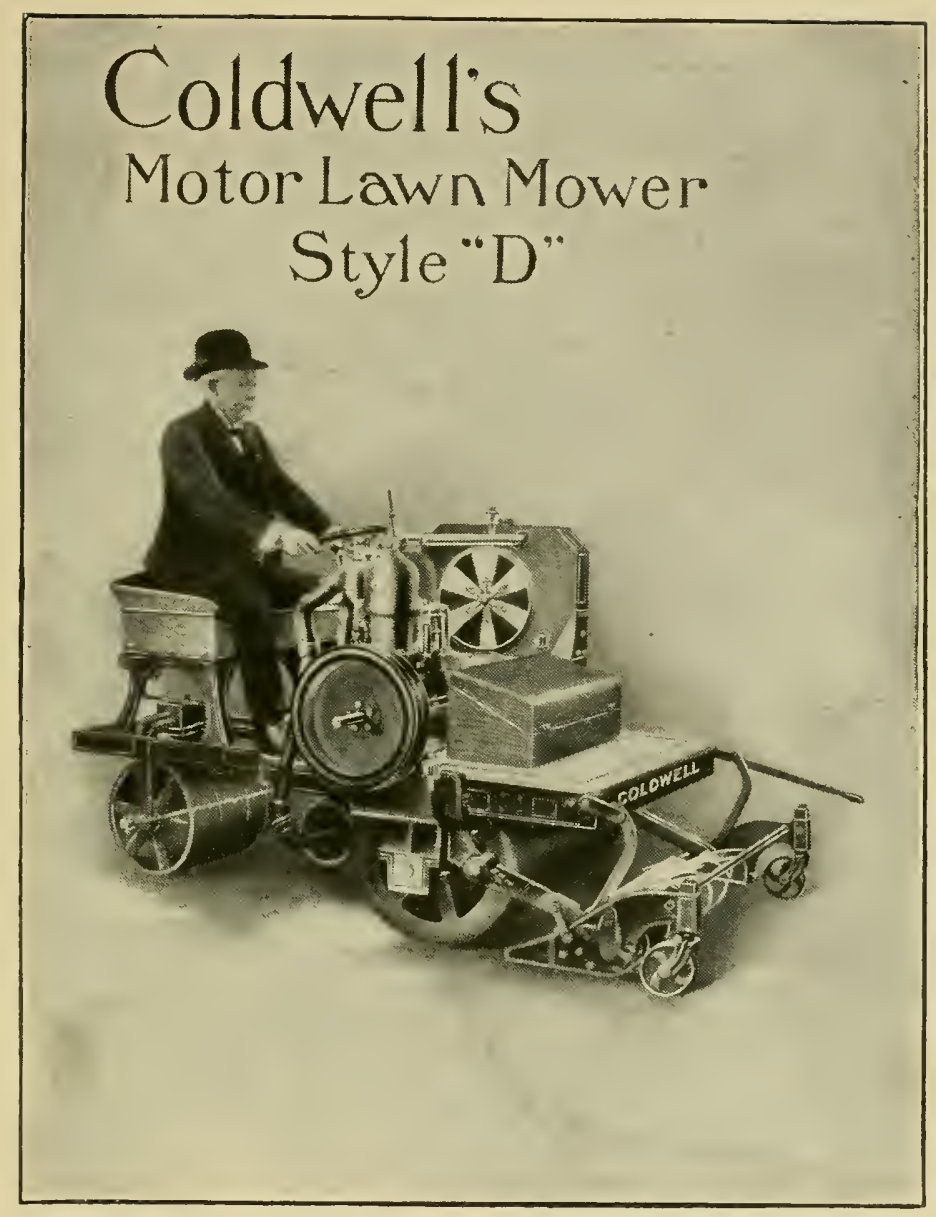

The machine weighs 2,000 pounds, and will negotiate 25 per cent. grades. It consumes from $1 / 2$ to $3 / 4$ of a gallon of gasoline per hour, cuts a 40-inch swath, and will do three times as much work in a day as any ordinary horse lawn mower. Will almost pay for itself in a single season.

Price, $\$ 1,300$ net, f. o. b. New York City. Terms, strictly net cash on delivery.

\section{CAN BE SEEN IN OUR WAREHOUSE}

Cireular on applieation 
野AK I I 1900 


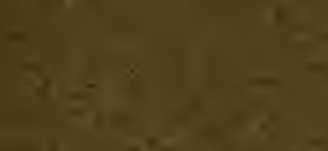

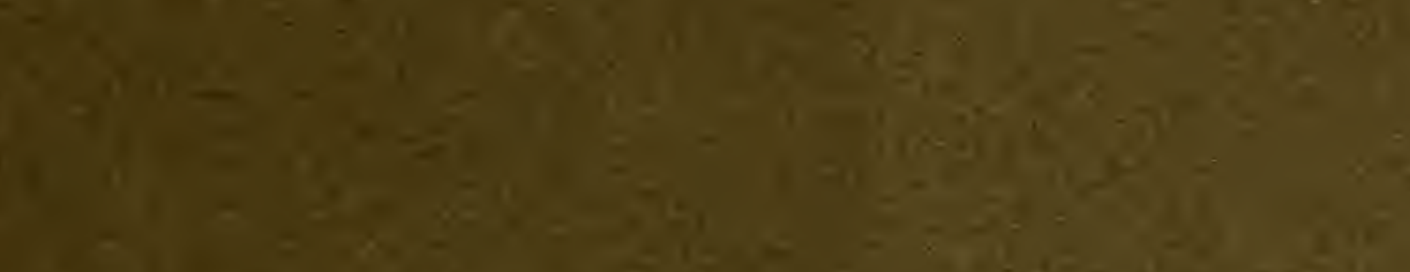

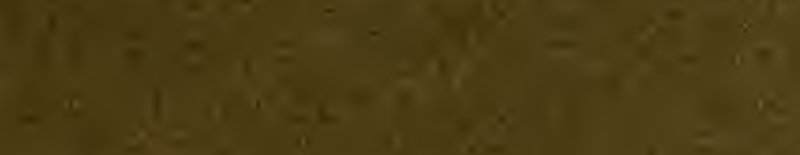

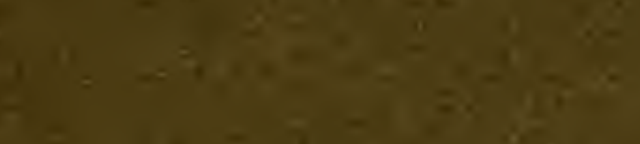

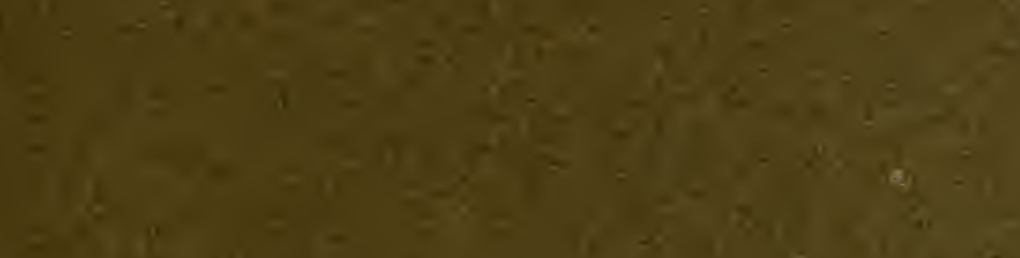

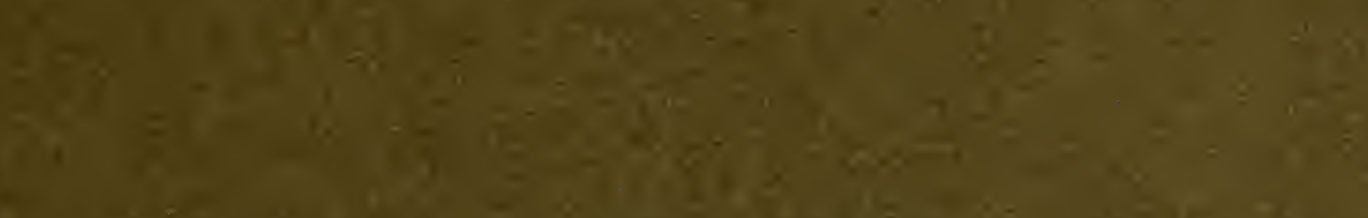

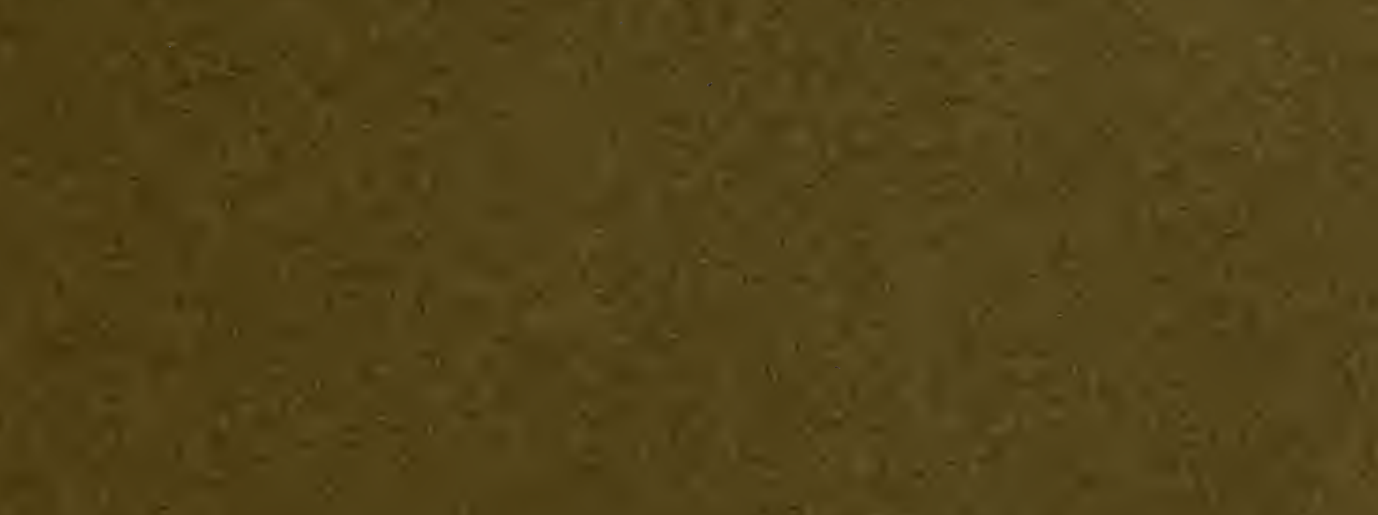

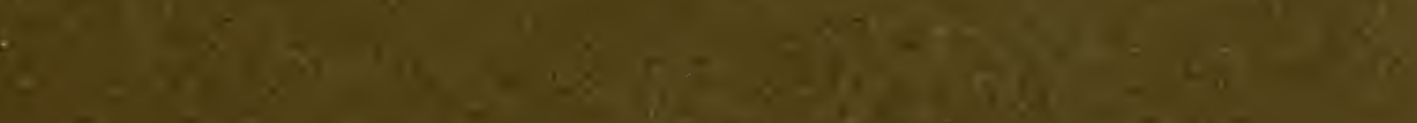

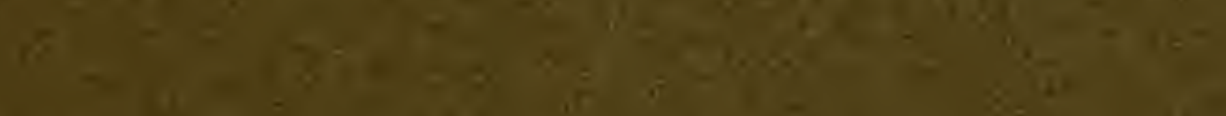

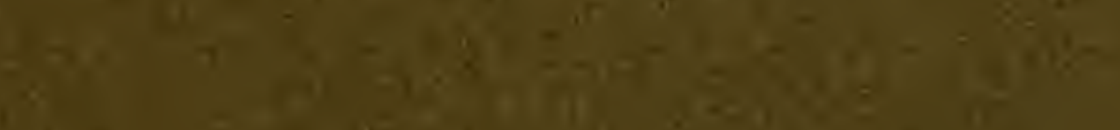

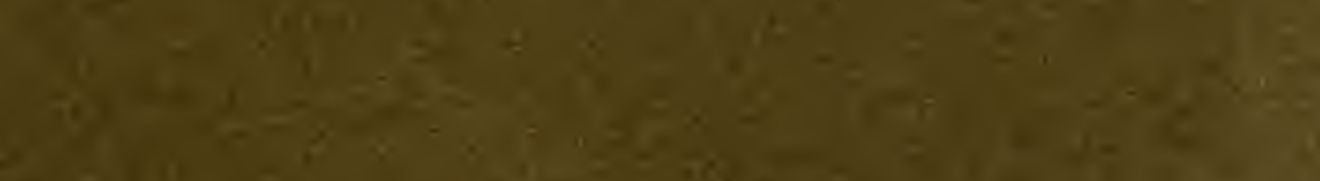




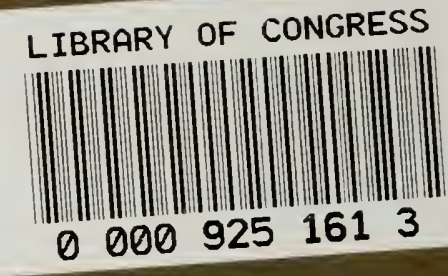

